\title{
A New Species of Polygala (Polygalaceae) from Brazil
}

Author(s): José Floriano Barêa Pastore and Taciana Barbosa Cavalcanti

Source: Novon: A Journal for Botanical Nomenclature, 18(1):90-93.

Published By: Missouri Botanical Garden

https://doi.org/10.3417/2005130

URL: http://www.bioone.org/doi/full/10.3417/2005130

BioOne (www.bioone.org) is a nonprofit, online aggregation of core research in the biological, ecological, and environmental sciences. BioOne provides a sustainable online platform for over 170 journals and books published by nonprofit societies, associations, museums, institutions, and presses.

Your use of this PDF, the BioOne Web site, and all posted and associated content indicates your acceptance of BioOne's Terms of Use, available at www.bioone.org/ page/terms_of_use.

Usage of BioOne content is strictly limited to personal, educational, and noncommercial use. Commercial inquiries or rights and permissions requests should be directed to the individual publisher as copyright holder. 


\title{
A New Species of Polygala (Polygalaceae) from Brazil
}

\author{
José Floriano Barêa Pastore \\ Universidade Estadual de Feira de Santana, BR 116, Km 03, Campus Universitário, \\ Departamento de Ciências Biológicas, Secretária de Pós-Graduação em Botânica, \\ CEP 44031-460, Feira de Santana, BA, Brazil. jfpastore@hotmail.com
}

\section{Taciana Barbosa Cavalcanti}

Embrapa Recursos Genéticos e Biotecnologia, Embrapa Cenargen, Parque Estação Ecológica, Final W5 Norte, CP 02372, CEP 70.770-900, Brasília, DF, Brazil.

taciana@cenargen.embrapa.br

Abstract. One new species for Polygalaceae from Brazil is described, illustrated, and compared with related species of Polygala L. subg. Hebeclada (Chodat) S. F. Blake. Polygala marquesiana J. F. B. Pastore \& T. B. Cavalcanti is an attractive caespitose subshrub from the state of Goiás, occurring in the high-altitude areas of Serra Geral do Paranã in the central part of the Brazilian savannas.

Resumo. Uma nova espécie de Polygalaceae para o Brasil é descrita, ilustrada e comparada com espécies relacionadas de Polygala L. subgênero Hebeclada (Chodat) S. F. Blake. Polygala marquesiana J. F. B. Pastore \& T. B. Cavalcanti é um belo subarbusto do estado de Goiás, que ocorre em elevadas altitudes da Serra Geral do Paranã, na porção central do cerrado brasileiro.

Key words: Brazil, IUCN Red List, Polygala, Polygalaceae, subgenus Hebeclada.

Expeditions in Brazil have been undertaken to increase the knowledge of the Brazilian Polygalaceae. These efforts have resulted in the collection of many interesting plants of the family, a number of which represent rare and endemic species. Polygala L. is first among the 18 genera in number of species in the Polygalaceae, with about 730 recognized species (Paiva, 1998) and 180 Brazilian species (Marques, 1979, 1984). The genus is widely distributed in all continental areas globally except in the Arctic, Antarctic, and New Zealand (Paiva, 1998), with the greatest diversity concentrated in South America. Ongoing efforts to revise Polygala species in the state of Goiás, within the central Brazilian savanna, have confirmed the presence of one species as undescribed in the genus.

The subgenus Hebeclada (Chodat) S. F. Blake is morphologically well delimited from the other subgenera of Polygala (Marques, 1979) by the upper posterior sepals, which are almost fully connate, with the style curved at a $90^{\circ}$ angle and 4-5 times longer than the ovary and with the keel ecristate. Some studies, such as those of Eriksen (1993) and Persson (2001), provide evidence that subgenus Hebeclada would be better treated as a distinct genus. However, the application of a generic name for this taxon depends not only on the results of a phylogenetic analysis, but also on a question of nomenclature regarding the status of Rafinesque's generic name Alsemeia, previously used by Small (1933).

Polygala subg. Hebeclada is only known from continental America (Marques, 1979) with a total of about 22 species. Members of the group are well represented in the Brazilian flora, the majority of which are endemic to high-altitude serras of the Campos Rupestres biome. In the Chapada dos Veadeiros of Goiás State alone, 12 species have been identified, four of which are endemic: P. xyloclada Chodat, Polygala sp. ined. 1, Polygala sp. ined. 2, and P. marquesiana.

Polygala marquesiana J. F. B. Pastore \& T. B. Cavalcanti, sp. nov. TYPE: Brazil. Goiás: Alto Paraíso, povoado de São Jorge, beira da estrada para Colinas do Sul, após $4 \mathrm{~km}$ de São Jorge, ca. $14^{\circ} 11^{\prime} 48^{\prime \prime} \mathrm{S}, 47^{\circ} 50^{\prime} 34^{\prime \prime} \mathrm{O}, 16$ Nov. 2007 (fl), Pastore et al. 2325 (holotype, CEN; isotypes HUEFS, K, MO, NY, RB). Figure 1.

Polygala marquesiana ad subgen. Hebecladam (Chodat) S. F. Blake sepalis superioribus externis fere omnino connatis et carena non cristata pertinens. Polygalae hebecladae DC. affinis sed bracteis post anthesim persistentibus et trichomatibus in foliis caulibusque sericeis differt. Ab omnibus speciebus subgeneris Hebecladae disco basi ovarii praesentia et foliis distalibus linearibus differt.

Caespitose herbs 25-36 cm tall, less congested distally; stems 1.8-2 mm diam., cylindric, rigid, 


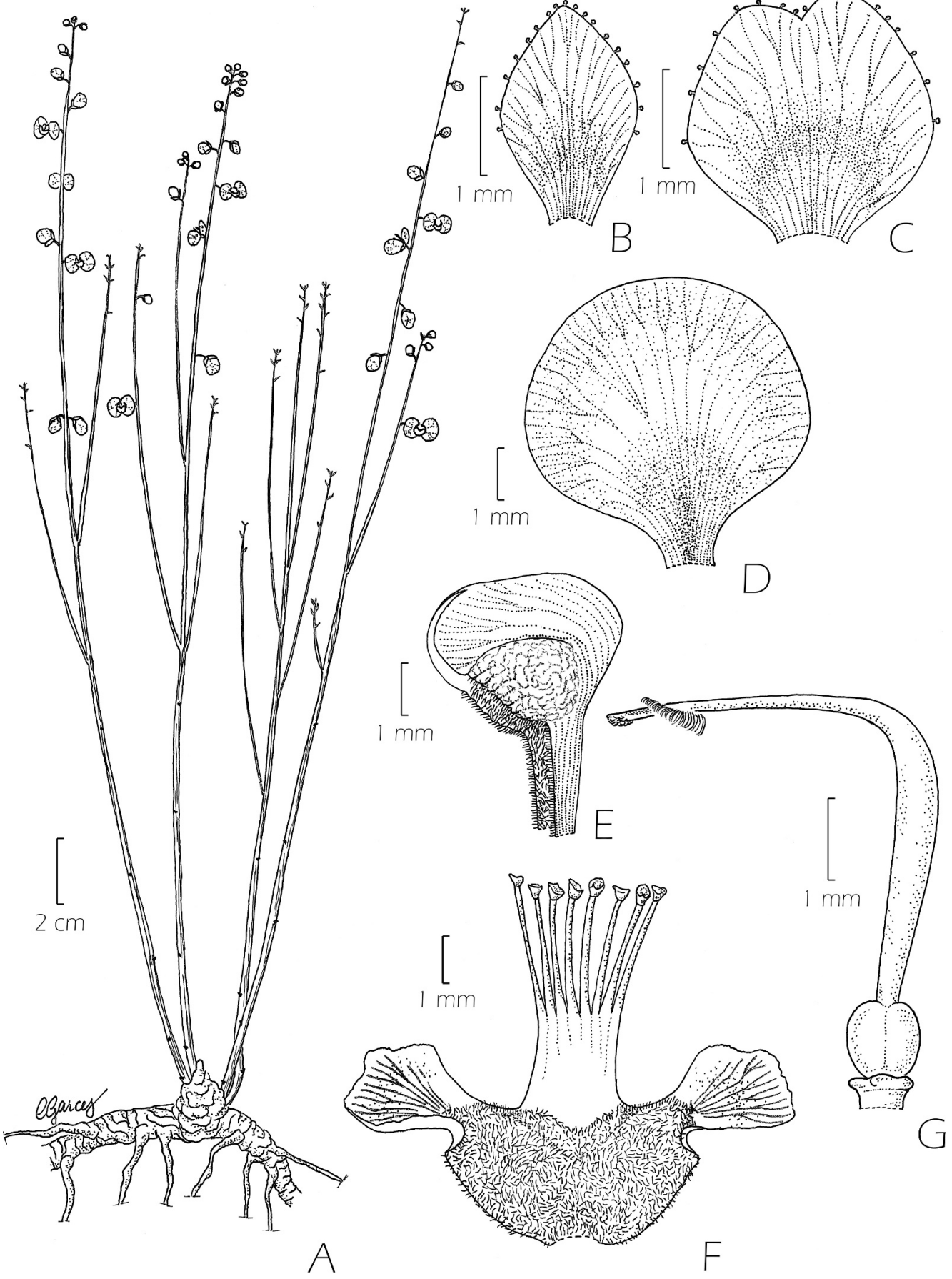

Figure 1. Polygala marquesiana J. F. B. Pastore \& T. B. Cavalcanti. - A. Habit. -B. Inferior outer sepal. —C. Superior outer sepals. - D. Inner sepal. —E. Carina. - F. Androecium and lateral petals. —G. Gynoecium with disc around the ovary base. Drawn from the holotype, Pastore \& Suganuma 218 (CEN).

glaucous, green to purple at the base, glandularpunctate, trichomes glandulous and sparse, basally more concentrated; roots fleshy, well developed, white to yellow. Leaves minute in size, $1-4 \times 1-3 \mathrm{~mm}$, diminishing in size toward stem-apex, linear, caducous, green to purple when young, glabrous to glabrescent, subsessile. Terminal raceme $3-10 \mathrm{~cm}$, lax; rachis striate, glabrous or with sparse simple 
Table 1. Morphological comparison of Polygala marquesiana and related species.

\begin{tabular}{lcllll}
\hline \hline & & & Indument of & & \\
& Inner sepals (wings) & Pedicel & stems & Leaf & Bracts \\
\hline P. xyloclada & suborbicular & curved & puberulent & elliptic to oval & subpersistent \\
P. rhodoptera & suborbicular & curved & pubescent & elliptic to oval & persistent \\
P. hebeclada & elliptic & erect or patent & pubescent & elliptic to oval & persistent \\
P. marquesiana & suborbicular & curved & puberulent & linear & caducous \\
Polygala sp. ined. 1 & elliptic & curved & pubescent & linear & persistent \\
\hline
\end{tabular}

trichomes, glandular-punctate; pedicel $2-3 \mathrm{~mm}$, curved in fructification, glabrous or with fine, sparse trichomes; bracts and bracteoles glabrous, linear, delicate, caducous, the central ones $2 \mathrm{~mm}$, the lateral ones $0.3 \mathrm{~mm}$. Flowers $6-8 \mathrm{~mm}$; outer sepals subequal, green, sometimes purple, subfleshy, apex acute, concave, venation dichotomous, conspicuous, glandular trichomes on the margin; the inferior sepal 3.6-3.9 $\times 3-3.1 \mathrm{~mm}$; the superior sepals $2.5-2.8 \times 2.7-$ $3 \mathrm{~mm}$, almost completely connate to the margin; inner sepals (wings) $5.3-6 \times 5.3-6.5 \mathrm{~mm}$, suborbicular, lilac, equal to or shorter than the carina, apex rounded, venation dichotomous, conspicuous; lateral petals ca. $5 \times 2.1 \mathrm{~mm}$, lilac with transverse white stripes toward apex, rose to white toward base, apex rounded, basally puberulent on ventral side; keel 5$5.7 \mathrm{~mm}$, deep lilac, not cristate, almost trilobate, puberulent on the inner surface, apex yellow; base ciliate, 4.6-5 mm, unguiculus $1.4-1.8 \mathrm{~mm}$, cuculus $3.6-4.3 \mathrm{~mm}$ wide; style bent in middle at ca. $90^{\circ}$ angle, stamens 8, filaments white, glabrous; anthers ca. $0.5 \times 0.4 \mathrm{~mm}$, slightly obovate, yellow; ovary ca. $0.8 \times 0.8 \mathrm{~mm}$, suborbicular, glabrous, pale green; disc around ovary base ca. $0.18 \times 0.9 \mathrm{~mm}$. Mature fruits not seen; immature capsules elliptic, green; seeds oblong, white, puberulent with white trichomes.

Distribution and IUCN Red List category. Despite the fact that neither of the two collecting sites, which are about $55 \mathrm{~km}$ apart at between 810 and $1010 \mathrm{~m}$ elevation, falls within a conservation area, the area between them and adjacent areas form part of the Chapada dos Veadeiros National Park (Goiás). It is probable, therefore, that further populations will eventually be found in the intervening areas, where access is necessarily more restricted. Our fieldwork indicates that the new species almost certainly has a total population of less than 1000 individuals. We therefore recommend that it be considered Vulnerable (VU D1) according to IUCN Red List criteria (IUCN, 2001).

Phenology and ecology. Polygala marquesiana is unmistakable in the field, with its deep lilac, showy flowers, caespitose habit, and presence of glandular trichomes on the stems. Polygala marquesiana is not only morphologically different from other members of the subgenus, but also displays unusual ecological features. Polygala marquesiana is rarely found fertile because the plant flowering occurs as a response to burning. This species was collected again with flowers (Pastore et al. 2325) after 12 subsequent visits in different months in the same area, where it was collected for the first time (Pastore \& Suganuma 218). It is worth noting that, during all this period, no fires occurred in the collection area. Pastore et al. 2325, as well as the paratype, which was collected in Cavalcante, were found in an area recovering from recent fires.

It should be noted that individuals were more than a meter apart in the field but were actually linked by a fleshy root system. This indicates the importance of vegetative reproduction in this species, which could compensate for infrequent flowering, and could also explain why the species is so poorly represented in the herbaria that we visited.

Etymology. The epithet honors Brazilian botanist Maria do Carmo Mendes Marques, of the Rio de Janeiro Botanical Garden, the noted authority on Polygalaceae of South America, who has collected many interesting Polygalaceae during the course of her investigations and has published both important contributions and new species for the family.

Relationships. Closely related species (Polygala hebeclada, P. rhodoptera Martius ex A. W. Bennett, P. xyloclada, and Polygala sp. ined. 1) are analyzed in Table 1.

Paratype. Brazil. Goiás: Goiás: Alto Paraíso, povoado de São Jorge, beira da estrada para Colinas do Sul, ca. $14^{\circ} 10^{\prime} 46^{\prime \prime} \mathrm{S}, 47^{\circ} 49^{\prime} 01^{\prime \prime} \mathrm{O}, 4$ Jan. 2003 (fl), Pastore \& Suganuma 218 (CEN). Cavalcante: ponte sobre o rio Tocantins, Km 79, $13^{\circ} 40^{\prime} 50^{\prime \prime} \mathrm{S}, 47^{\circ} 52^{\prime} 35^{\prime \prime} \mathrm{O}$, 30 Oct. 2004, Cavalcanti et al. 3523 (BR, CEN, MO).

Acknowledgments. The authors acknowledge the herbarium staff at CEN for making material available, Elisa Suganuma for assisting in the field, Raymond M. Harley for reviewing the manuscript, Tarciso Filgueiras for preparing the Latin diagnosis, and Cristina Garcez for drawing and inking the illustration. Funding was provided through Conselho Nacional de Desenvolvimento Científico e Tecnológico (CNPq) grant no. 300976/95-0. 


\section{Literature Cited}

Eriksen, B. 1993. Phylogeny of the Polygalaceae and its taxonomic implications. Pl. Syst. Evol., Vienna, 186(1-2): $33-55$.

IUCN. 2001. IUCN Red List Categories and Criteria, Version 3.1. Prepared by the IUCN Species Survival Commission. IUCN, Gland, Switzerland, and Cambridge, United Kingdom.

Marques, M. C. M. 1979. Revisão das espécies do gênero Polygala L. (Polygalaceae) do Estado do Rio de Janeiro. Rodriguésia 31(48): 69-339, est. 1-84.
1984. Polygala grazielae Marques-Uma nova espécie de Polygala L. para o Mato Grosso do Sul. Rodriguésia 36(58): 17-20.

Paiva, J. A. R. 1998. Polygalarum Africanum et madagascariensium prodromus atque gerontogæi generis Heterosamara Kuntze, a genere Polygala L. segregati et a nobis denuo recepti, synopsis monographica. Fontqueria 50(4): 1-15.

Persson, C. 2001. Phylogenetic relationships in Polygalaceae based on plastid DNA sequences from the trnL-F region. Taxon 50(3): 763-779.

Small, J. K. 1933. Pp. 765-774 in Manual of Southeastern Flora. Univ. of North Carolina Press, Chapel Hill. 